\title{
The Effects of High Fowler and Orthopneic Position in Lung Ventilation; A Quantitative-Experimental Study
}

\author{
Agussalim \\ Poltekkes Kemenkes Jayapura, School of Nursing, Medical Surgical Department, Padang Bulan 2 Hedam, Kota Jayapura, Papua, Indonesia
}

\begin{abstract}
COPD is lung crhonik desease with obstruction of air flowing caracterictic which is nonreversible progresivity and reversible partial with lung inflammation response to the dangerous particel in the air. This research aims to understand the effect of Highfowler and Orthopneic Position Significantly to the function of lung ventilation of clients with COPD in Internist ward of Labuang Baji Hospital 2014. This research is a quantitatif research with experimental method (Quasy-Experiment) by pre test-post test group design. Sample of this research are clients with COPD who are attending in Internist ward of Labuang Baji Hospital by Purposive sampling technik. The result of this research shows Highfowler and Orthopneic position influenced to decrease of respiratory rate frequency and increase the Peak Flow Expiration of the COPD clients with a significantly result of Highfowler position $(P 1=0,000)$ and $P 2=0,000)$ and significantly result to Orthopneic Position $(P 3=0,000$ and $P 4=0,000)$. Based on the result, $i$ could conclude that there was influencing of Highfowler and Orthopneic position to the lung of ventilation functioning of COPD Clients in Internist Ward of Labuang Baji Hospital Makassar City. My suggestion is to the the hospital and all nurses applying of Highfowler and Orthopneic Position giving care to the client with COPD in order to increase the function of lung ventilation.
\end{abstract}

Keywords: High Fowler, Orthopneic, Lung Ventilation, COPD

\section{Background}

COPD is one of the desease which disturbs of Oksigen need by characterictic of air flowing obstuction in respiratory tract with nonreversible progresive, reversible partial, and lung inflammation in particel and air dangerous seriuosly (Gold, 2005).COPD is the one cause of Morbidity and Mortality number increased in the world. WHO applied the day of COPD day is November 18 . WHO predicted at early of 2020 , the prevalence of of COPD clients will increase from the twelve to the fith rating in the world.

In 2002, 2004 and 2005, the number of clients with COPD in develop countries around $3,9 \%, 3,5 \%$ and $3,9 \%$. In developing countries, the number of COPD around 7,6\%, 7,4 and $8,1 \%$. The number if poor country is lower than develop and developing country such us $3,1 \%, 3,6 \%$ and $3,4 \%$.

In SEAMIC health statistic 2001 shown that Bronchitic, Emfishema and Astma are caused of the seventh grade of mortality case in Indonesia. In Survey Kesehatan Rumah Tangga (SKRT) Ministry of Health of Indonesian Republic 2002 shown that the number of COPD inside the country around $12,7 \%$. Based on the Data of Ministry of Health of Indonesian Republic South Sulawesi Region (Makassar City), the number of clients with COPD in 2008 until 2009 is 292 cases and in 2010 is predominantly increased around 450 cases. In medical record of Labuang Baji Hospital in 2009 and 2010, there were around 120 cases and 162 cases with COPD.

\section{Statement of the Problem}

Based on the data above, $i$ tried to formula the question of the research " is there an efffect of Highfowler and Orthopneic position to the function of lung ventilation of the client of COPD in Internist Ward of Labuang Baji Hospital Makassar City?"

\section{The Purpose of Study}

\section{General Purpose}

To undesrtand the effect of Highfowler and Orthopneic position to the functioning of lung ventilation of COPD Clients.

\section{Specific Purpose}

1. To understand the function of lung ventilation before giving Highfowler with COPD Client in Labuang Baji Hospital.

2. To understand the function of lung ventilation before giving Orthopneic with COPD Client in Labuang Baji Hospital.

3. To understand the function of lung ventilation after giving Highfowler with COPD Client in Labuang Baji Hospital.

4. To understand the function of lung ventilation after giving Orthopneic with COPD Client in Labuang Baji Hospital.

5. To understand the effectiveness to the function of lung ventilation with giving highfowler and orthopneic position to the clients with COPD in Labuang Baji Hospital.

\section{Method of Research}

\section{Research Design}

This research is a quantitatif research by using QuasyExperiment with Pre and Post Test Design. This research aim to identity the effect of intervention (Sastroasmoro, 2002).

Population and Sample 


\section{International Journal of Science and Research (IJSR) \\ ISSN (Online): 2319-7064}

Index Copernicus Value (2013): 6.14 | Impact Factor (2014): 5.611

The population in this research are client who are diagnosed by Medical of Doctor with COPD in Internist Ward of Labuang Baji Hospital around 30 of June until 18 of July 2013. Sampling technique using in this research is Purposive Sampling with Inclusive and Eksklusive Criteria. The number of sample is this research around 15 respondens

\section{Legal Ethics of This Research}

1) Informed consent

2) Anonimity

3) Confidentiality

\section{Data Collecting}

1) Observation Paper

2) Peak Expiratory Flow Meter (PEF Meter)

3) Stopwatch, to calculate the RR of Clients

\section{Data Intervention \\ 1) Editing \\ 2) Coding \\ 3) Tabulating, \\ 4) Entry data, \\ 5) Cleaning data.}

\section{Data Analysis}

1) Univariate Analisys

2) Bivariate Analisys

It is used to each variable with using Paired Sample $t$ Test by $\alpha=0,05$ or $5 \%$ Margin Error. Hypotesis Alternative will be accepted if $\mathrm{p}<\alpha=0,05$ by using software SPSS versi 11.5

\section{Result}

Univariate Analisys

Sample distribution based of Demograpic Characteristic (Sex, Age, Height and Weight).

Table 1: Sample distribution based on sex in internist ward of Labuang Baji Hospital

\begin{tabular}{|l|l|l|}
\hline Characterictic & $F$ & $\%$ \\
\hline Male & 10 & 66,7 \\
Female & 5 & 33,3 \\
\hline Total $\left(\sum\right)$ & 20 & 100 \\
\hline
\end{tabular}

Source: Primary Data, Juni-Juli 2013

Based on the table 1 above, we could understand the sample distribution based on sex such us male around 10 people $(66,7 \%)$ and female around 5 people $(33,3 \%)$.

Table 2: Sample distribution based on age in internist ward of Labuang Baji Hospital

\begin{tabular}{|l|l|l|}
\hline Characteristic & $F$ & $\%$ \\
\hline Age (year) & & \\
$30-40$ & 4 & 26,7 \\
$41-50$ & 5 & 33,3 \\
$51-60$ & 5 & 33,3 \\
$>60$ & 1 & 6,7 \\
\hline Total $\left(\sum\right)$ & 15 & 100 \\
\hline
\end{tabular}

Source: Primary Data, June-July 2013

Table above shows sample distribution based on age with predominantly age between $41-50$ and 5060 years old about
5 each $(66,6 \%)$. Then age between $30-40$ are 4 people $(26,7 \%)$ and age more than 60 years is only 1 person $(6,7 \%)$.

Table 3: Sample distribution based on age in internist ward of Labuang Baji Hospital

\begin{tabular}{|l|l|l|}
\hline Characteristic & $F$ & $\%$ \\
\hline Weight (Kg) & & \\
$40-45$ & 4 & 26,7 \\
$46-50$ & 10 & 66,7 \\
$51-55$ & 1 & 6,7 \\
\hline Total ( $\sum$ ) & 15 & 100 \\
\hline
\end{tabular}

Source: Primary Data, June-July 2013

Based on table 3 above, we could explain that weight sample between $46-50 \mathrm{~kg}$ around 10 people $(66,7 \%), 40$ to $45 \mathrm{~kg}$ are 4 people $(26,7 \%)$ and 51 to $55 \mathrm{~kg}$ is only one $(6,7 \%)$.

Table 4: Sample distribution based on age in internist ward of Labuang Baji Hospital

\begin{tabular}{|l|l|l|}
\hline Characteristic & $F$ & $\%$ \\
\hline Height $(\mathrm{Cm})$ & & \\
$150-155$ & 3 & 20,0 \\
$156-160$ & 11 & 73,3 \\
$161-170$ & 1 & 6,7 \\
\hline Total $\left(\sum\right)$ & 15 & 100 \\
\hline
\end{tabular}

Source: Primary Data, June-July 2013

Based on table 3 above, we could explain that height sample between 156 to $160 \mathrm{Cm}$ around 11 people $(73,3 \%), 150$ to $155 \mathrm{Cm}$ are 3 people $(20,0 \%)$ and 161 to $170 \mathrm{Cm}$ is only one $(6,7 \%)$.

\section{Bivariate Analysis}

It is used to see the effect of Highfowler and Orthopneic Position to the function of lung ventilation to the client with COPD in Internist Ward of Labuang Baji Hospital Makassar.

Table 5: Sample distribution client with COPD based on the number of Respiratory Rate (Pre-Post Giving High Fowler

Position) in internist ward of Labuang Baji Hospital.

\begin{tabular}{|c|c|c|c|c|c|c|c|c|c|}
\hline \multicolumn{8}{|c|}{ Respiratory Rate (High fowler) } & \multirow{3}{*}{\multicolumn{2}{|c|}{ Total }} \\
\hline \multicolumn{4}{|c|}{ Pre } & \multicolumn{4}{|c|}{ Post } & & \\
\hline \multicolumn{2}{|c|}{ Normal } & \multicolumn{2}{|c|}{ apnea } & \multicolumn{2}{|c|}{ Normal } & \multicolumn{2}{|c|}{ apnea } & & \\
\hline $\mathrm{n}$ & $\%$ & $\mathrm{n}$ & $\%$ & $\mathrm{n}$ & $\%$ & $\mathrm{n}$ & $\%$ & $\mathrm{n}$ & $\%$ \\
\hline 0 & 0 & 10 & 66,7 & 3 & 20,0 & 7 & 46,7 & 10 & 66,7 \\
\hline 0 & 0 & 5 & 33,3 & 4 & 26,7 & 1 & 6,7 & 5 & 33,3 \\
\hline 0 & 0 & 15 & 100 & 7 & 46,7 & 8 & 53,3 & 15 & 100 \\
\hline
\end{tabular}

Source: Primary Data, June-July $2013 \mathrm{p}_{1}=0,000$

Based on table 5 Above, we could say that the number of sample who under supervising around 15 samples. 10 sample with male sex $(66,7 \%)$ and 5 sample as female $(33,3 \%)$ with apnea condition. After giving intervention by High Fowler Positioning 3 males show normal respiratory rate $(20,0 \%)$ and 7 males show still in apnea $(46,7 \%)$. Female sample show normal respiratory rate around $4(26,7 \%)$ and only one sample who is still in apnea condition $(6,7 \%)$.

Table 6: Sample distribution client with COPD based on Peak Flowing Expiration (Pre-Post Giving High Fowler Position) in internist ward of Labuang Baji Hospital. 


\section{International Journal of Science and Research (IJSR) \\ ISSN (Online): 2319-7064}

Index Copernicus Value (2013): 6.14 $\mid$ Impact Factor (2014): 5.611

\begin{tabular}{|c|c|c|c|c|c|c|c|c|c|}
\hline \multicolumn{7}{|c|}{ Value of PFE (High fowler) } & \multicolumn{3}{c|}{ Total } \\
\hline $\begin{array}{c}\text { Pell } \\
\text { Pe }\end{array}$ & $\begin{array}{c}\text { Bad } \\
\text { Ventilalation }\end{array}$ & $\begin{array}{c}\text { Well } \\
\text { Ventilation }\end{array}$ & \multicolumn{2}{c|}{$\begin{array}{c}\text { Bad } \\
\text { Ventilation }\end{array}$} & \multicolumn{3}{c|}{} \\
\hline $\mathrm{n}$ & $\%$ & $\mathrm{n}$ & $\%$ & $\mathrm{n}$ & $\%$ & $\mathrm{n}$ & $\%$ & $\mathrm{n}$ & $\%$ \\
\hline 0 & 0 & 10 & 66,7 & 6 & 40,0 & 4 & 26,7 & 10 & 66,7 \\
\hline 0 & 0 & 5 & 33,3 & 3 & 20,0 & 2 & 13,3 & 5 & 33,3 \\
\hline 0 & 0 & 15 & 100 & 9 & 60,0 & 6 & 40,0 & 15 & 100 \\
\hline
\end{tabular}

Source: Primary Data, June-July $2013 \mathrm{p}_{2}=0,000$

Based on table 5 Above, we could say that the number of sample who under supervising around 15 samples. 6 samples $(40,0 \%)$ who are males showing well ventilation and 4 samples are still bad ventilation (26,7\%). In another side, 4 samples who are females after giving High Fowler positioning showing 4 samples in well ventilation $(20,0 \%)$ and 3 females are bad ventilation $(13,3 \%)$.

Table 7: Sample distribution client with COPD based on Observation (Pre-Post Orthopneic Position) in internist ward of Labuang Baji Hospital

\begin{tabular}{|c|c|c|c|c|c|c|c|c|c|}
\hline \multicolumn{8}{|c|}{ Respiratory Rate (Orthopneic) } & \multirow{3}{*}{\multicolumn{2}{|c|}{ Total }} \\
\hline \multicolumn{4}{|c|}{ Pre } & \multicolumn{4}{|c|}{ Post } & & \\
\hline \multicolumn{2}{|c|}{ Normal } & \multicolumn{2}{|c|}{ Apnea } & \multicolumn{2}{|c|}{ Normal } & \multicolumn{2}{|c|}{ Apnea } & & \\
\hline $\mathrm{n}$ & $\%$ & $\mathrm{n}$ & $\%$ & $\mathrm{n}$ & $\%$ & $\mathrm{n}$ & $\%$ & $\mathrm{n}$ & $\%$ \\
\hline 0 & 0 & 10 & 66,7 & 5 & 33,3 & 5 & 33,3 & 10 & 66,7 \\
\hline 0 & 0 & 5 & 33,3 & 4 & 26,7 & 1 & 6,7 & 5 & 33,3 \\
\hline 0 & 0 & 15 & 100 & 9 & 60,0 & 6 & 40,0 & 15 & 100 \\
\hline
\end{tabular}

Source: Primary Data, June-July $2013 \mathrm{p}_{3}=0,000$

Based on the table 7 above, it is explaining that after giving intervention with orthopneic Positioning aroun 5 samples who are male showing 5 samples with normal respiratory rate $(33,3 \%)$ and 5 samples with still in apnea respiratory $(33,3 \%)$. In female samples after giving Orthopneic positioning 4 samples are showing in well respiratory rate ( $26,7 \%$ ) and 1 sample is still in bad respiratory rate.

Table 8: Sample distribution client with COPD based on PFE (Pre-Post Orthopneic Position) in internist ward of Labuang Baji Hospital

\begin{tabular}{|c|c|c|c|c|c|c|c|c|c|}
\hline \multicolumn{7}{|c|}{ Peak Flowing Expiration (Orthopneic) } & \multicolumn{3}{c|}{ Total } \\
\hline $\begin{array}{c}\text { Well } \\
\text { Ventilation }\end{array}$ & $\begin{array}{c}\text { Bad } \\
\text { Ventilation }\end{array}$ & \multicolumn{3}{c|}{$\begin{array}{c}\text { Well } \\
\text { Ventilation }\end{array}$} & \multicolumn{2}{c|}{$\begin{array}{c}\text { Bad } \\
\text { ventilation }\end{array}$} & \multicolumn{3}{c}{} \\
\hline $\mathrm{n}$ & $\%$ & $\mathrm{n}$ & $\%$ & $\mathrm{n}$ & $\%$ & $\mathrm{n}$ & $\%$ & $\mathrm{n}$ & $\%$ \\
\hline 0 & 0 & 10 & 66,7 & 6 & 40,0 & 4 & 26,7 & 10 & 66,7 \\
\hline 0 & 0 & 5 & 33,3 & 4 & 26,7 & 1 & 6,7 & 5 & 33,3 \\
\hline 0 & 0 & 15 & 100 & 10 & 66,7 & 5 & 33,3 & 15 & 100 \\
\hline
\end{tabular}

Source: Primary Data, June-July $2013 \mathrm{p}_{4}=0,000$

Based on the table 8 above, 6 samples $(40,0 \%)$ who are males after having intervention with orthopneic positioning has well ventilation and 4 samples $(26,7 \%)$ have bad ventilation. In another side, 4 females samples ( $26,0 \%)$ have well ventilation and only one has bad ventilation after intervention $(6,7 \%)$.

Table 9: Influenced of Highfowler Position to the Function of Lung Ventilation of Client with COPD in Internist Ward of Labuang Baji Hospital

\begin{tabular}{|l|l|l|l|l|}
\hline Highfowler & Pre Test & Post Test & Changed & Sig. \\
\hline
\end{tabular}

\begin{tabular}{|c|c|c|c|c|c|}
\hline Position & Mean & Mean & Mean & T & \\
\hline $\begin{array}{c}\text { Respiratory Rate } \\
\text { PFE }\end{array}$ & 22,33 & 21,13 & 1,20 & 8,290 & 0,000 \\
429,27 & 448,13 & $-18,87$ & $-6,932$ & 0,000 \\
\hline
\end{tabular}

Source: Primary Data, June-July $2013 \mathrm{p}_{1}=0,000 \& \mathrm{p}_{2}=0,000$

Based on the Table 9 above shows the mean of Respiratory Rate pra intervention around 22,33 and post intervention around 21,13. In other side, the grade of Peak Flowing Expiration pra intervention 429,27 L/Minutes and Post Intervention 448,13 . The mean of respiratory rate changing is around 1,20 and grade of Peak Flowing Expiration is 18,86 . The number of respiratory rate counted around $t_{\text {hit } 1}=$ 8,290 and PER is $t_{\text {hit } 2}=-6,932$. Based on SPSS output was understood grade by $t_{\text {hit }}>t_{\text {tab }}$ with $t_{\text {tab }}=1,761$. In order to see the significant result where $p_{1}=0,000 \& p_{2}=0,000$. Based on that result which $\mathrm{p}<0,05$ meaning to say that $\mathrm{H} 0$ Rejected and $\mathrm{Ha}$ Accepted that there was influenced of Highfowler position to Clients with COPD.

Table 10: Influenced of Orthopneic Position to the Function of Lung Ventilation to the client with COPD in Internist Ward of Labuang Baji Hospital

\begin{tabular}{|c|c|c|c|c|c|}
\hline $\begin{array}{c}\text { Orthopneic } \\
\text { Position }\end{array}$ & Pre Test & Post Test & \multicolumn{2}{|c|}{ Changed } & \multirow{2}{*}{ Sig. } \\
\cline { 2 - 5 } & Mean & Mean & Mean & $\mathrm{t}$ & \\
\hline Respiratory Rate & 21,87 & 20,80 & 1,07 & 9,025 & 0,000 \\
PFE & 437,40 & 455,07 & $-17,67$ & $-8,156$ & 0,000 \\
\hline
\end{tabular}

Source: Primary Data, June-July $2013 \mathrm{p}_{3}=0,000 \& \mathrm{p}_{4}=0,000$

Based on table 10 above, mean of repiratory rate pre test around 21,87 and post test around 20,80 moreover the rate of Peak Flowing Expiration pre test 437,40 and post test 455,07 . Then rate of respiratory rate changing around 1,07 and rate of Peak Flowing Expiration changing is around 17,67. Negative sign means rate of post test more than pre test. $\mathrm{T}_{\text {hit }}$ is 9,025 and $-8,156$ and $\mathrm{t}_{\mathrm{tab}}=1,761$ so $\mathrm{t}_{\text {hit }}>\mathrm{t}_{\text {tab }}$ with significant lower than $5 \%(0,05)$ where $\mathrm{p}_{3}=0,000 \& \mathrm{p}_{4}=0,000$ $(p<0,05)$. Based on the result, we could say that Ho is rejected and $\mathrm{Ha}$ is accepted that there was influence of of Orthopneic position to the lung function to the client with COPD.

\section{Explanation of The Study}

1. The result of this study shows Highfowler and Orthopneic position influenced to decrease of respiratory rate frequency and increase the Peak Flow Expiration of the COPD Clients with a significantly result of Highfowler position $(\mathrm{P} 1=0,000)$ and $\mathrm{P} 2=0,000)$ and significantly result to Orthopneic Position (P3 $=0,000$ and $\mathrm{P} 4=0,000)$

2. Based on the result above, i could conclude that there was influencing of Highfowler and Orthopneic position to the lung of ventilation functioning of COPD Clients in Internist Ward of Labuang Baji Hospital Makassar City.

\section{Discussion}

This study given the real data that highfowler and orthopneic position can be used as part of nursing intervention in the 


\section{International Journal of Science and Research (IJSR) \\ ISSN (Online): 2319-7064}

Index Copernicus Value (2013): 6.14 | Impact Factor (2014): 5.611

clinical area. Another side, nurses must be understand the need of the client who has COPD problem. Given a hidgfowler and orthopeneic position make the inspiration and expiration of the client becoming regular. The composistion of the oxygen inside of the lung becoming optimum in order to decrease of lungs distress.

\section{Suggestion}

1. This study should be developed again by Qualitative research to make clear and briefly

2. Orthopneic and High fowler position should be aplicated by nurses to deliver care for clients with COPD in the clinical area.

3. Orthopneic and high fowler position should be placed it as one topic inside the subject in nursing curriculum.

\section{References}

[1] Aditama, T.Y. (2005). Paru kita masalah kita. http:// tempointeraktif.com/ medikal arsip/1120002/top-1- htm diakses 12 mei 2011

[2] Azwar , A. \& Prihartono, J. (2003). Metodologi kedokteran \& kesehatan masyarakat. Batam: Binarupa aksara

[3] Aziz, H. (2007). Riset Keperawatan dan Teknik penulisan Ilmiah. Jakarta : Salemba Medika

[4] Anas,Tamsuri.2008. Klien Gangguan Pernafasan: Seri Asuhan Keperawatan. Jakarta :EGC.

[5] Brunner \& Suddarth.(2001). Buku ajar keperawatan medikal bedah. Edisi 8, EGC, Jakarta.

[6] Bhatt, S.P.(2007). effect of tripod position on objective parameters of respiratory function in stable COPD. http://www.meeting.chestjournal.org/ cgi/contnt/abstract/172132694/610b, diperoleh 14 mei 2011

[7] Danusantoso, Halim. (2000). Buku Saku Ilmu Penyakit Paru. Hipokrates. Jakarta.

[8] Depkes RI. (2007). Profil kesehatan Indonesia 2005. Jakarta

[9] Herger, Barbara R.(2003). Sistem keperawatan: Suatu pendekatan proses keperawatan. Edisi.6. Jakarta: EGC

[10] Guyton A.C \& Hall J.E. (1997). Buku ajar Fisiologi kedokterang textbook of medical Physiology. Terjemahan Irawati S., Ken Ariata. T. Alex Santoso. Edisis 9. EGC Jakarta.

[11] Global Initiative for Chronic Obstructive Lung Disease (GOLD), (2005), pocket Guide to COPD Diagnosis, Managemen, and Prevention, dari http:// www.goldcopd.org, diakses 22 juni 2011

[12] Jain, Prasoon. (1998).Utility of Peak Expiratory Flow Monitoring. CHEST The Cardiopulmonary and Critical Care Journal.

[13] Ikawati,Zullies.(2007).farmakoterapi penyakit sistem pernafasan. Pustaka adipura : Jogjakarta

[14]Kozier.(2000). Fundamental of Nursing : Concepts, Prosess and Practice : Sixthedition, Menlo Park, Calofornia.

[15] Kline, S.G.(2007). Predicting ventilatory function from weight .www.spirxpert.com/Revalve. htm. Diperoleh 11 mei 2011
[16]Lapier .(1999). Sitting and standing position affect pulmonary function $i$ patient with COPD. http://findarticles.com /p/articles/miqa3955/15- 1999/aid8845045, diperoleh 11 mei 2011

[17] Menaldi, Rasmin.(2001). Prosedur Tindakan Bidang Paru dan Pernapasan, Diagnosa dan Terapi. Jakarta: Bagian Pulmonologi FK UI.

[18] Monahan,F.F \& Neighbors, M.(2000). medical surgical nursing : foundation for clinical practice. Philadelphia

[19]Murwani ,Arita.2008. Perawatan Pasien Penyakit Dalam. Jogjakarta : Mitra Cendikia

[20] Nursalam. (2009). Konsep dan penerapan metodologi penelitian ilmu keperawatan. Jakarta: Salemba medika.

[21] Price SA dan Wilson, L.M.,(2005), Patofisiologi konsep klinis Proses-proses Penyakit. Edisi.6. Jakarta: EGC

[22] Somantri, Irman.(2008). Keperawatan Medikal Bedah: Asuhan Keperawatan Pada Pasien dengan Gangguan Sistem Pernafasan . Jakarta: Salemba Medika

\section{Author Profile}

Agussalim, i received my first Nurse Education From Labuang Baji in 1996 then continued to Akper Anging Mammiri 2003, Sulawesi Selatan. My Bachelor of Science Nursing (S.Kp) from Binawan Institute of Health Science in 2006 then my Master of Science Nursing (MSN) and Master of Science Teaching (MST) from Saint Paul University Philippines in 2009 ans 2010. Doctor of Nursing Science (DNS) received from the same university in The Philippines in 2015. Now i am working as a teacher in Nursing School of Ministry of Health, Poltekkes Jayapura, Papua, Indonesia. 